Article

\title{
Turbulent Trajectories: African Migrants on Their Way to the European Union
}

\section{Joris Schapendonk}

International Development Studies, Faculty of Geosciences, Utrecht University, Heidelberglaan 2, 3508 TC, Utrecht, The Netherlands; E-Mail: j.schapendonk@uu.nl; Tel.: +31-30-2531402

Received: 15 December 2011; in revised form: 10 April 2012 / Accepted: 12 April 2012 /

Published: 17 April 2012

\begin{abstract}
Sub-Saharan African migration towards the European Union (EU) belongs to one of the most stigmatized forms of migration of the $21^{\text {st }}$ century. It is strongly characterized by EU's restrictive migration policies. As a consequence, migrants who are aspiring to reach the EU often undertake fragmented and dangerous journeys to the North. This contribution attempts to gain more empirical insights into these migratory journeys. It is based on a 'trajectory ethnography' that combines in-depth interviews with sub-Saharan Africans, who are waiting in Morocco and Turkey to enter the EU, with a longitudinal strategy to follow some of these respondents over longer periods of time. With this longitudinal element I was in particular able to grasp expected steps and unexpected turns in individual migration trajectories. By discussing three main components (the motivation, facilitation and velocity) of journeys, this contribution puts into perspective the unidirectional and often frictionless metaphors of migration - as if migrants move like 'flows' and 'waves'.
\end{abstract}

Keywords: migration trajectories; sub-Saharan Africa; EU; transit migration; borders

\section{Introduction}

In the last decade, images of sub-Saharan African migrants attempting to reach the European Union (EU) have been widely disseminated in European media. These images often focus on the most spectacular moments of migrants' journeys: The moments when they jump from fences, arrive exhausted in unseaworthy boats at European islands, or hide in fully packed cargo trucks. These glimpses of migration journeys tend to reinforce the public perception of African migrants as 'desperate invaders' or 'poor victims of smuggling networks' [1]. Furthermore, the news messages that 
belong to these images, regularly present this migration from the global South with the apocalyptical undertone of an 'African exodus' or 'African invasion' [2]. In this context, it is safe to state that sub-Saharan African migration towards the EU belongs to one of the most stigmatised forms of human movement of the $21^{\text {st }}$ century.

This contribution aims to provide better empirical insights into the journeys of sub-Saharan African migrants who are heading for the EU. By including the dynamics of migrants' travel before and after the sensational border crossings that are caught by various media, it attempts to create a completer and in-depth picture of what it means to be 'on the road' in a geo-political context in which borders are closing.

\section{African Aspirations and European Borders: Turbulent Migrations to the North}

We live in the 'age of migration' [3]. With the approximately 214 million international migrants we have today [4], international migration has reached even the most isolated areas of the globe. If people do not move themselves, they are often closely connected to those who have migrated across state borders. As a cumulative effect, global interconnectedness triggers the longing to move to an 'elsewhere' as images about 'the good life' are easily transmitted across the world with the help of new media and communication technologies [5-7].

Although Africa is often regarded as a relatively disconnected continent of the globe, I stress that it is certainly not entirely isolated from processes of globalization. In the first place, Africa is linked to the rest of the world by its diasporas keeping contact with their communities in the countries of origin. Secondly, African societies are also increasingly connected by the means of Internet access and mobile telephony [7,8]. Mobile phones have even reached areas that have always lacked access to landlines [8]. As a result of both older and newer connections, the aspiration to reach better places is omnipresent in many African societies $[9,10]$.

These migration aspirations emerge in times that the EU closes its borders. From the perspective of European states, migration from the South is first and foremost perceived as a security issue [11]. In line with this, the outer borders of the EU have been fortified, as in the case of the Spanish enclaves Ceuta and Melilla in Morocco. Other borders are staffed with 'special forces' to combat illegal migration, as with the new 'Rapid Border Intervention Team' (RABIT), installed in Greece in 2010. The digitalization of border controls, including the installation of transnational data-bases, is also part of this security paradigm [12]. Finally, EU border controls are shifting southwards. This implies that migrants sending countries are involved in lucrative 'migration deals' providing them with development aid in exchange for stricter border regulations and border controls. Cape Verde, for instance, has received between 2007 and 2009 some $€ 27$ million from the Spanish government in exchange for stronger cooperation to combat irregular migration. For similar reasons, the European Commission has granted Mali with €426 million in development aid over a period of five years [13]. Moreover, EU's neighbouring countries, such as Turkey and Morocco, have been increasingly approached by their European 'partners' as 'buffer zones' that are asked to stem so-called transit migration [14]. 
Due to EU's restrictive border politics there have been over 3,700 migration-related fatalities at EU's border since the turn of the $21^{\text {st }}$ century [15]. Nothing more convincingly demonstrates that globalization means rather social closure and blocked access for the least fortunate [16].

The increased connectedness of African societies and the restrictive geopolitical climate of the EU with regard to African migration contribute both to a 'turbulent' picture of migration [17]. The notion of the turbulence of migration stresses the multi-causality and multi-directionality of contemporary migration. At the same time, the term turbulence points to the frictions occurring with migration as states and supra-states do their best effort to control the movements of (some) people [17]. Turbulence can then be seen as a welcome alternative to the often used migration metaphors of flows and waves that suggest that migration patterns are unidirectional, possibly invasive, and encounter little resistance [18].

\subsection{Fragmented Migration to the North}

The increase of migration aspirations in times of restrictive migration policies in the EU is an important explanatory factor of contemporary irregular migration from Africa to the EU. Because most of the conventional roads are blocked, a considerable group of sub-Saharan African migrants undertakes fragmented and risky journeys to 'the North' [18-20]. Several main migration routes can be identified in this respect.

Firstly, the Atlantic route from the West African coast to the Canary Islands (belonging to Spain) appeared to be a popular route for sub-Saharan Africans to reach the EU. In the year 2006, over 30,000 sub-Saharan Africans arrived at Spanish territory by embarking fragile boats heading for the Canaries. A second important route is the trans-Saharan route from West Africa to Morocco from where migrants hope to make the 'final jump' to Spain [2]. This final jump might imply entering one of the Spanish enclaves or reaching the Spanish coast by boat. Thirdly, many sub-Saharan African migrants have followed the central Mediterranean pathway through Libya or Tunisia from where European islands such as Malta or Lampedusa (Italy) can be reached [21]. Fourthly, and more recently, subSaharan Africans also go to Turkey, mostly by airplane, from where they try to enter Greece. Generally, migrants reach Greece by boat or by crossing the Greek-Turkish land-border in the Evros region. However, Turkey is an important crossroad for migrants from all regions of the world [22]. It follows that sub-Saharan Africans are only marginally present in data on irregular migration in this region [23].

By discussing these irregular migration routes from Africa to Europe, it is relevant to note that these routes change from year to year. The number of arrivals in one region can be quite high during one year and drop substantially in the next, possibly to rise again some years later. The numbers of irregular arrivals at the Canary Islands, for instance, dropped from over 30,000 in 2006 to 9,600 in 2008 because of stricter sea controls. In the same period, however, the central Mediterranean route to Lampedusa became more important, with 21,400 arrivals in 2006 and 31,300 arrivals in 2008 [24]. This number dropped again in 2009 to 6,790 arrivals in the first six months (the number of arrivals was at least twice as high in the first six months of 2008) [25]. While the central Mediterranean route has become less important in the last few years, the route from Turkey to Greece has become increasingly popular. The overland route to Greece has been identified by the EU border agency FRONTEX as the 
last 'leak' in the EU's southern border regime [18]. The border agency has estimated that $80 \%$ of the total number of irregular migrants to the EU passes through Greece.

In this context it is also vital to note that, although the numbers of unauthorized entries appear to be substantial, they have only a minor impact on the statistics on immigration to the EU. The 30,000 boat entries at the Canary Islands in 2006, for instance, account for only $0.8 \%$ of the total non-EU population in Spain for that year [26]. Finally, it is worth mentioning that the majority of irregular migrants in the EU has not crossed the border by unauthorized means. Most irregular migrants in the EU are visa-overstayers or rejected asylum seekers [2,27]. Hence, it is not so much the invasion of 'illegals' that is shaping irregular migration to the EU, but rather the limited duration of travel documents and the number of unsuccessful asylum applications in the EU.

\section{Understanding Migration Trajectories}

Main routes and main entry points can be identified, but these general patterns provide little information about the dynamics of individual migration journeys.

Migration researchers have shown an increasing interest in the 'in-between phase' or 'mobility phase' of migration. Research on social networks [28,29] and smuggling practices [30], for example, has gained interesting insights into the issue how social and not-so-social connections facilitate migration processes. In addition, research on so-called transit migration has yielded valuable information on migrants' in-betweenness while they are moving to their destinations [14,20,21,31]. However, the knowledge that is gained is rather fragmentary. Social networks have been mostly investigated in isolation from smuggling networks, and most studies distinguish regular from irregular migration. Furthermore, although the debate on transit migration has led migration scholars to think more thoroughly about the in-between phase of migration, we seldom come to know how the transit phase relate to other phases of the migration process [32]. This contribution therefore takes the journey in its complete sense as its analytical focus. It investigates how the legal/illegal, the smuggler/helper and the mobile/immobile come together in individual migration trajectories

\subsection{A Trajectory Ethnography}

The findings of this study are based on my $\mathrm{PhD}$. research (2007-2011), which is presented as a trajectory ethnography [18]. The bulk of information is gathered by the means of in-depth interviews with sub-Saharan Africans who are on their way to the EU. The fieldwork started with an explorative trip to Spain, Morocco and Senegal. During this trip, the first contacts with migrants and migration related institutions were established. Subsequently, I went to Morocco (Rabat and Oujda) and Turkey (Istanbul) in order to collect migration biographies [33] of migrants coming from West - and Central African countries. In total I interviewed 57 migrants in these countries about their journeys. In addition, I interviewed some 50 sub-Saharan Africans who are living in the EU about their migration journeys.

All the interviews with sub-Saharan Africans in Morocco and Turkey had a rather informal and conversation-like character. The research data are a product of my interpretation of migrants' subjective experiences and, therefore, they are not based on any form of objectivity [18]. An important issue to come to a profound understanding of the 'turbulent trajectories' of my respondents is the 
creation of a trust-relationship between me and the respondent. For this reason, the interviews were conducted in places where the respondent felt comfortable when speaking about their trajectories. Almost half of the interviews in Morocco and Turkey occurred in migrants' homes. Other interviews in these countries were conducted in cafés, churches or in the open air. During the interviews I deliberately did not make use of recording technologies. Evidently, the disadvantage of this 'off-therecord' approach is that one runs the risk of losing some relevant data. It may also affect the credibility of the data, as the written versions of the interviews are based on products of the researcher's ad-hoc understanding of what is being said. Hence, the quotes presented in this paper represent a combination of migrants' verbal expressions and my own interpretations of these expressions. However, I believe that the absence of recording technologies certainly contributed to the trustworthy environment that is a precondition for carrying out qualitative research on this often sensitive topic.

As with any research on irregular migration, this project includes some serious ethical considerations. After all, details about specific people and specific strategies may harm individuals in the near future. In this respect it is important that the researcher explicitly explains his project goals to their respondents. Moreover, it is crucial that any participation in the project is entirely voluntary. Finally, and almost self-evidently, the researcher must guarantee the anonymity of his respondents. These are the required steps in the field. But I believe the researcher can do more than that, without falling into the naïve rhetoric of the project being directly beneficial to the respondents. With an open interview approach, there are many opportunities to embed the agenda of migrants more prominently in the research project. One of the opportunities is that the researcher gives the respondent a voice in terms of the topics that will be addressed during the interview. Another opportunity is that the open interview approach creates room for the respondent to raise questions to the researcher leading to a situation in which information is transferred in both directions.

Besides these open interviews, I have used a longitudinal strategy in this research project. Because I have been ethnographically engaged with some of my respondents, I have been able to maintain contact with them after I had left the fieldwork locations in Morocco and Turkey. In total, I have followed seven migrants whom I have met in Morocco (three Congolese, two Cameroonians, and two Nigerians) and six migrants whom I have met in Turkey (four Nigerians, one Burundian, and one migrant from the Comoros). Unfortunately, all longitudinal respondents were male. Although I have interviewed fourteen female migrants in EU's transit spaces, all attempts to connect with them for a longer period of time failed for various reasons [18]. Notwithstanding, these longitudinal cases were particularly helpful to understand the course of individual trajectories. Through telephone conversations and Internet chats I have been kept updated about migrants' travel experiences. These translocal connections also enabled me to revisit some migrants in the different countries they ended up. I revisited respondents in respectively the Netherlands, France, Italy and Greece. In these countries, I was part of their everyday life for various periods of time [18]. This paper focuses predominantly on these longitudinal cases because they explicitly reveal the twists and turns in migration trajectories.

\subsection{Three Main Components of Trajectories}

To understand the dynamics of migrants' journeys, I conceptualise the main unit of analysis as 'the trajectory.' It follows that I do not take the individual migrant - the actor - as the point of departure, 
but the trajectories whereby migrants' decisions are only one of the many factors that affect the trajectory. Migrants' trajectories are not closed-off corridors but open and process-like phenomena [18]. They are influenced by, among others, the trajectories of other people, objects, capital, rules and information. From such a relational perspective, the evolutions of various trajectories depend so much on a 'thrown-togetherness' of factors [34] at certain moments in certain places [35]. The task of the researcher then is to make sense of this 'thrown-togetherness' in order to understand the courses of the trajectories. As a starting point, I distinguish three main components of journeying. These are:

- The motivation for the journey. Whether the move is voluntary or forced, every migrant has a motivation to move, even if concrete goals or destinations have not been formulated. I define the motivation to move as the migration aspiration. Migrants' aspirations differ analytically from migrants' intentions as the former concept is not directly linked to feasible plans and may include dreams, wishes, and future perspectives [36].

- The facilitation of the journey. A migrant may have the motivation to move, but every journey needs some facilitation as well. Some aspects of journeys can be facilitated by the migrant themselves. However, without the help of others (this might be, among others a family member, a border guard, a co-migrant, a stranger) migrants do not get very far. For this reason the facilitation of the journey is sought in migrants' connections with other people.

- The motivation and facilitation give journeys a certain direction. However, these two issues reveal little about the fast- and slowness of the journey. The third main component to analyse trajectories is, therefore, the velocity of journeys [37]. In this context, migration trajectories are not only about mobility, but even so about periods of rest, re-orientation and (un)expected and (un)intended temporary or long-term settlements [18,38]. By taking these issues into account, I focus on the physical and experienced mobility and immobility of migrants in order to know more about the velocity of the trajectories.

In the remainder of this paper I present the dynamics of migrants' trajectories by elaborating on these three components of journeys. Thereby I focus on the thirteen longitudinal cases of my study. The following three sections all start with two snapshots of the trajectories of different migrants. These snapshots are further discussed by relating them to the trajectories of other migrants. Thus, although I do not take the migrant as the unit of analysis, I do take purposively the perspective of the migrant to understand their trajectories.

\section{Dynamic Motivations and Shifting Destinations}

In my country there is no future ... Everybody knows it and many people go out. They just go! I did the same, just go! I went to Nigeria to look for work ... At that time, I did not think of Europe, Nigeria was promising, the economy was booming, so you go there and you search for a place ... I had a good life there. But then you hear about Nigerians leaving for Europe, you hear about success and so on. One day, three of my [Nigerian] friends created the plan to go, and I wanted the same ... Now [in Morocco] I want to reach Spain. I will stay there for one year. Then I will go to Paris or London, and if there is a chance, I will go to New York or Washington!

(Sony, Cameroon, 22 years old. Explaining how his migration to Nigeria influenced his aspiration to reach Europe. Interview in Oujda (Morocco), January 2008) 
Of course I wanted to go to Europe, of course I dreamed about that, but what can I say? When you were young, didn't you have your own dreams? That does not mean that you can manage it in reality ... I know that Europe is not a paradise now, I hear that. So I can go, but the question is what can I do? With no papers, no proper education ... No, at the moment, it is better to stay for me.

(Jean-Louis, Democratic Republic of Congo, 36 years old. Talking about his aspiration to stay in Morocco. Interview in Rabat (Morocco), January 2008).

When we read the two quotes, we learn how the aspirations of Sony and Jean-Louis have been subjected to change over time. Sony went to Nigeria as his first destination. He only was thinking of going to Europe after hearing success stories of Nigerian migrants going there. Jean-Louis, on the other hand, explains how his migration project was initially attached to Europe but changed over time into a project that was more oriented towards a long stay in Morocco.

The changeability of their aspirations becomes even more interesting by noting that Jean-Louis did actually arrive in the EU, and Sony finally returned to Cameroon. One year after the interview in Rabat, Jean-Louis informed me by email that he was very discouraged about life in Morocco after a violent accident with the son of his boss. During several telephone conversations he explained me how he was able to borrow a passport from an African migrant living in the UK. With this passport he was able to take a ferry to Spain from where he moved onwards to France. Sony, on his turn, had tried several times to cross the Moroccan-Spanish border, but all his attempts failed. Because he was depressed about his situation in Morocco, he decided to go home, to Cameroon. Yet, as he explained me during a telephone conversation, in Cameroon he has not giving up his aspiration to reach Europe one day. In that sense, a return does not necessarily mean the end of a migration process.

The trajectories of the other migrants I have followed show some similar dynamics. Due to the dangers of the irregular passage to the EU from respectively Morocco and Turkey, and due to the high costs that are related to these journeys, several migrants gave up their hopes of reaching the EU. Of the thirteen longitudinal cases, one Nigerian migrant in Istanbul decided to return home, and two other Nigerians (one in Istanbul and one in Rabat) decided to build a life in the places they initially attempted to pass.

Similar to Sony's case, other respondents explained me how 'Destination Europe' only appeared to them along the way. One of them is a Burundian man who gained a scholarship to study at one of the universities of Istanbul. His initial plan was to finish his study in four years and return to Burundi in order to become a doctor there. However, due to the immense working load, his struggle with the language and daily discriminations in Turkey, he started to think about an eventual irregular crossing to Greece in order to building up a life in Europe. Another illustrative case is that of a Congolese migrant whom I have met in Morocco. During several conversations, he emphasised he had a role to play in the Moroccan society. He even created a Congolese migrant organisation to make the Moroccan society more sensitive for the presence of African migrants. However, as he was selected by the UNHCR for resettlement, the outcome of his migration project turned out to be quite different than his aspiration revealed at the specific moment of the interview. Instead of being in Morocco, he is now living in the Netherlands as a result of his resettlement process. These cases indicate the possible shifting of destinations during the migration process. 
Besides these shifting destinations, it is also worth noting that some of the migrants had rather persistent aspirations of reaching Europe. Several respondents have even made five life-risking attempts to cross European borders. In the literature on transit migration it is emphasised that transit migrants in European borderlands have rather utopic notions of Europe. Europe is often considered as one big and abstract destination [18,20,32,39]. In other words, Spain and Greece are seen by migrants as access points from where the rest of the EU can be easily reached. Jean-Louis, the Congolese man quoted at the beginning of this section, travelled overland through Spain in order to reach France. Two other migrants, originating from the Comoros and Nigeria, reached Greece after a transit period in Istanbul. From Greece they moved respectively to France and Switzerland. In this context, Europe, as an abstract destination, becomes more concrete along the way.

Whereas most migration studies focus on the motivation at the moment of departures, these findings indicate altogether that motivations may change along the way and that migration trajectories do not always occur according to well-considered plans. As Ralph Grillo [40] suggests, trajectories are rather multiple sets of trajectories in which destinations shift and are possibly in-between. In other words, migrants are on the move, but so too are their aspirations.

\section{Moving and Mediating: Migrants' (Dis)Connections}

I started my project without telling my mother, without telling my father. Only my older brother advised me. We discussed a lot of things, the difficulties, the dangers and so on. He also gave me some money to finance the journey. Then I went to Kano first [a town in northern Nigeria]. I looked for traders to transport me to Zinder [a border town in Niger]. There I met three other Nigerians. We were the Nigerian Crew. We were like brothers, you become good friends because you have to trust each other. We eat together, sleep together and arrange transport together.

(Eric, Nigeria, age 26. Talking about his overland journey from Nigeria to Morocco. Interview in Rabat (Morocco), January 2008)

During a follow-up interview in Italy, Eric elaborated on his desert crossing by saying:

People who want to cross to Algeria, they pass Agadez [a migration hub in Niger]. You discuss it with people in Zinder. In Agadez we [the Nigerian crew] had to look for a good connection man, the border with Algeria is not easy to cross ... It is the desert, you know! ... In Morocco everybody has its own plan, so we separated. I went together with my friend to Rabat, the other friends stayed in Oujda [a border town in Morocco] to reach Europe from there.

(Eric, Nigeria, age 26. Talking about his overland journey from Nigeria to Morocco. Interview in Prato (Italy), November 2008)

You give the contractor the money. That is someone you can trust, in my case it was a good friend ... The contractor must have a reason to stay, so you give him 10\% of the price. After you arranged this, you go to Izmir [a port-town South of Istanbul] and take a small boat to Greece. When you have reached Greece, you call the contractor to give the money to the connection man ... If you don't reach Greece, you don't pay and you can try again with the same money.

(Joseph, age 27. Talking about how migrants arrange their passage from Turkey to Greece. Interview Istanbul, April 2008) 
Migrants usually need other people's efforts to be capable of moving. These efforts are not only needed for the organisation of the journey in the pre-migration phase (before the journey starts) as a successful passage might also require some coordination, and possibly reparation, during the act of moving [41]. The above snapshots show how migrants make strategic social connections to guarantee their passages. Eric's Nigerian Crew is an 'en route collective' that helped him to overcome the dangerous crossing of the Sahara desert. Similarly, the contractor Joseph is talking about is a social connection that prevents someone to waste his/her money on a failed border crossing. The latter confirms the notion that migrants often have some spaces of negotiation in the smuggling process [30]. Moreover, it suggests that social networks and smuggling networks are not strictly separated, but that they may overlap in the migration process [31].

The theorization of migrants' social networks usually consists of strong ties (family members and good friends) and weak ties (connections outside the immediate circle of family and close friends) [42]. In other words, the relevant social connections that help migrants to get ahead are believed to be rather solid and durable ties. During my fieldwork in transit spaces I came across rather transient social ties that were important to migrants during their journeys. In Oujda, a Moroccan town near the Algerian border where the majority of migrants with overland journeys enter Morocco, for instance, informal settlements can be found where migrants live for a specific period of time. Some migrants attempt to reach Spanish ground from there. Others move to cities like Casablanca or Rabat in order to find work that helps them financing the 'final jump' to the EU. The communities in the informal settlements are at the same time constantly refreshed by newcomers who recently have entered Morocco via Algeria. Despite the transient character of these migrant communities, the social bondages in Oujda are vital to migrants as information concerning job opportunities and security issues is easily shared [18].

In Istanbul I gained insightful information on social connections in transit situations by the means of my ethnographic engagements with a group of five Nigerians who lived together in the same house. I have visited this house several times and during these visits the five friends emphasized their solidarity and friendship. They were "close brothers," as they called it. The fact that I met these Nigerians mostly as a collective, confirmed my notion of their close brotherhood. During my stay in Istanbul I collected their telephone numbers and email addresses to remain in contact with them. In this way I was able to observe the outcomes of the so-called 'transit phase' in relation to their friendship. In 2010, two of the five Nigerian friends were still living in Istanbul and they had regularly contact with each other. Two others had reached Greece in the meantime, and one of them moved further to Switzerland. One of the friends returned to Nigeria. Thus, none of the five Nigerian house-mates lived in the same house where I had met them some months earlier. The geographical dispersion illustrates the transient character of the collective. What is more interesting, however, is the fact that most of them became quite distant from each other in both the geographical and social sense. The two men who have reached Greece used to accompany each other day-in and day-out during their stay in Istanbul. But in the period they both lived in Athens, they seldom contacted each other. One of them commented on this as follows: "I don't see him very often. He is involved in different businesses, and he lives in a different area of Athens." Furthermore, when I told one of the Nigerians who are still living in Istanbul about the fact that his friends had reached Greece he sounded quite surprised: "Is it? I did not know that. That is good news! ... I didn't know that because I was not so engaged with these guys." 
What appeared to be a very solid collective at the time I visited their 'Nigerian house,' was thus not that solid after all. The transient character of the group does not mean that the social links between these five young men living together in the same house were superficial. It points rather to the way in which social connections are changeable in the dynamic context of migration trajectories. This issue of temporary attachments is widely recognized in travel literature, as it is well described by Eric J. Leed [43]:

"Journeys necessitate the ability both to form attachments and to break them. The traveler, in having to learn how to make contingent, transient, terminable relationships-which are not necessarily superficial_- "soon ... becomes accustomed to making friendships quickly, enjoying someone intensely, and then breaking off with little sorrow." (quote from J. W. Vogt 1978). The vulnerability of the solitary traveler, and the resulting fear, makes the traveler porous, needy, and alert to the possibilities of association."

When we analyze social connections during the act of moving, we thus come to a more dynamic version of networks that contrasts the grid-like understandings of strong and weak ties. Social connections function indeed as bridges that help migrants in their migration process. It is good to realize, however, that these bridges are actively built and need some active maintenance. Moreover, with the Nigerian collective as an illustrative example, we notice that the same social bridges sometimes fall down.

\section{Moving and Waiting: The (Im)Mobility of Migrants}

You think of moving to Europe, but that is difficult without money ... Going back?! That is not possible, I cannot go back! When you go back, people will ask me questions, and some people lent me money, you maybe know about that. I cannot go back. But that is not the only reason. This football agent [his smuggler] kept my return ticket. So tell me how can I afford a ticket to Nigeria? It is not possible! You cannot save money here, you cannot save money if you don't have a job ... I have been here for eight months, and if you told me eight months ago that this would be my life, I would never have left my country.

(Jude, Nigeria, age 24 years old. Expressing his frustrations about his immobility in Turkey. Interview Istanbul (Turkey), April 2008)

This country is not easy to pass, people do not stay here because they want to, people are forced to stay. I am in Oujda for a year now, but sometimes I live in Maghnia [a town at the Algerian side of the border] ... I also have been in Rabat, only for four days. But you know, the situation is good there. You can have a house, there are some jobs and you have a nice bed to sleep in. But there is one important thing I hate about that place. People forget where they are going to. They forget about Europe, they forget about their dreams and they lose their spirit ... I prefer to stay here [in Oujda] because every day when I wake up I realize that I have to go. Look around you; this is not a place to stay.

(Sony, Cameroon, age 22 years old. Explaining his (im)mobile life in Morocco. Interview in Oujda (Morocco), January 2008)

As the preceding snapshots demonstrate, one cannot merely focus on the 'moving parts' in order to grasp the dynamics of migrant trajectories [38]. The migration processes of sub-Saharan Africans who 
are passing through Morocco and Turkey are highly fragmented and include considerable periods of immobility. In terms of migrants' immobile statuses, roughly three groups can be distinguished [44]. There are 'stranded migrants' having the feeling that the EU borders have blocked their movement to the North. Sony, the Cameroonian man, can be seen as being stranded. Secondly, there are 'stuck migrants' experiencing a kind of immobility in almost every migratory direction, including that of their countries of origin. Jude is an example of a stuck migrant as he is not able to move onwards to the EU, but neither is he able to go back to Nigeria. Finally, there are more or less settled migrants; those migrants who are happy to stay in a supposed transit country.

It is already argued that migrants' aspirations are changeable. In line with this, migrants must not be regarded as being fixated in one of the three categories of immobility. A home-like feeling may change for the worse whereupon the migrant may decide to move again. Similarly, a transit-situation may become a home-like situation for the migrant in question. The latter is illustrated by Sony who is comparing the situation in Oujda, a place where migrants wait without having any interaction with the Moroccan society, with the situation in Rabat where African migrants slowly become more settled. Or to put it in his words, Rabat is a place where people forget that they are on the way to the EU.

In this respect, it is interesting to distinguish experienced immobility from physical immobility. Migrants who stress that they are rather immobile, may in fact move over short or long distances $[44,45]$. Many migrants stated to be on the move for security and economic reasons. Some respondents in Rabat (Morocco) emphasized that they never were begging for money in the same places in order to avoid problems with the local population and authorities. In Istanbul, many sub-Saharan Africans are involved in instant and mobile economic activities that are known as "chabuk chabuk", meaning 'do it quickly' or 'hurry up.' These fleeting activities, such as carrying heavy loads on markets and construction sites, are for the authorities difficult to control and are therefore reserved for migrants without a legal status [46].

Whereas the interview fragments of Jude points to the inability to cross international borders, Sony is moving across the Moroccan-Algerian border quite frequently. Thus, migrants who appear to be immobile may in fact cross international borders. In line with this, some Nigerian and Senegalese migrants in Istanbul explained me their strategy to actually commute between the country of origin and the supposed transit country in order to reach the EU. Before their visa for Turkey expires (usually after a period of three months), they return to their countries of origin because they know that a decent return makes it more likely that another visa application for the same country is successful. With the new visa, they may try again to reach the EU. In these cases, the transit phase has a rather circular and mobile character.

The migrants who have succeeded in reaching Europe after an immobile period in the European borderlands are frequently facing another waiting period in Europe; a period of detention. In almost all southern European countries, the detention periods for irregular migrants have been recently lengthened by the authorities. In Greece the maximum period of detention is six months, and for exceptional cases twelve months. In Italy, the period of detention has been determined at 180 days. In Spain this period is still forty days, while Malta is a rather extreme case as the maximum duration of detention is set at eighteen months, which is the uppermost limit allowed under the EU rules [47].

When the authorities are not able to identify the transit point and/or the country of origin of the detained migrant, the migrant is usually released with an expulsion order saying that he is obliged to 
leave the country in a limited period of time. This is the period in which many migrants become mobile again. It is, in this context, interesting to see where the longitudinal respondents have ended up. Only six of the thirteen migrants I have followed have reached the EU in the meantime. Here is an overview.

- Clement (46 years old, Democratic Republic of Congo) moved from Morocco to France by airplane. In France he recently applied for asylum.

- Jean-Louis (36 years old, Democratic Republic of Congo) moved from Morocco to Spain by boat by borrowing a passport. In Spain, he moved further northwards to France. There he applied for asylum.

- Eric (26 years old, Nigeria) moved from Morocco through Algeria and Libya and finally reached Italy. He is now living in Prato. There he found a girlfriend (from Nigeria, but with an Italian passport) who recently gave birth to Eric's child. The fact that he has become a father increases his chance for regularization in Italy.

- Destiny (31 years old, Nigeria), has reached Greece by boarding a fragile boat in Turkey. As he was not happy in Greece, he decided to move to Italy, from where he later reached Switzerland. There he applied for asylum. However, his application was rejected by the Swiss authorities. Thereupon Destiny decided to move to Italy again, where he is making new plans.

- Joseph (27 years old, Nigeria), reached Greece by boarding a fragile boat to a Greek island. He is nowadays commuting between Athens and the tourist island Corfu where he is involved in informal tourist services.

- Said (42 years old, Comoros), also reached Greece by boat. He applied for asylum by pretending he came from Somalia. His application was accepted. With his asylum papers he took an airplane to France. He is living at the moment as an irregular migrant in Marseille (he has thrown away his asylum papers).

Interestingly, only Eric and Clement stayed in the European country they had entered. The other four migrants crossed again some international border within the EU. This illustrates that a country of arrival is for the migrant not always the country where he is aiming to stay.

\section{Conclusions}

Migration is all too often regarded as a simple move from an origin to a destination [48]. In migration studies, the migrant is then regularly positioned as a (rational) actor deciding in place A how he will reach his destination, place B. In line with this, the journey is easily reduced to a meaningless in-between phase [37]. I have refuted this linear notion of migration by focusing on the trajectories of a very particular group of people; sub-Saharan Africans who are aspiring to reach the EU but have not obtained the right travel papers. For them, the journey towards the EU is highly fragmented, and border crossings occur seldom without turbulence. These particular trajectories have a process-like logic in which destinations are moving targets, social connections can be transient, and periods of mobility may easily change into periods of immobility, and vice versa.

Starting from such a dynamic perspective, we may critically reflect upon the public discourse of irregular migration that is outlined at the beginning of this article. This discourse, suggesting that 
irregular migration from Africa to Europe occurs with 'waves' of migrants 'flooding European territories', is often represented by migration maps showing big arrows that simply jump from one continent to the other. Most of these maps lack any notion of multi-directionality, fragmentation, and process [49] that characterize so many aspects of the trajectories I have investigated.

To analytically understand the dynamics of these trajectories, I argue that we have to consider together two meanings of the term 'trajectory.' On the one hand, there is the anthropological notion of a trajectory as a life or career path, suggesting that people have different aspirations and take different decisions at different stages in their lives [18]. This means that similar events have different values for migrants when they occur at different moments in their life paths $[1,50]$. On the other hand, there is the geographical trajectory, implying a movement across space. Without being a geographical determinist, I argue that the spatial evolution of a trajectory influences the continuation of the same trajectory. Being 'here' might evoke the longing to reach 'there,' and once one has arrived 'there,' another 'there' might emerge — or the aspiration to return 'here' might become prominent again [18]. Following this logic, it is not so much beginnings (the A) and endings (the B) that matter, but rather the in-between, the trajectory itself.

\section{References and Notes}

1. Bredeloup, S. Sahara Transit: Times, Spaces, People. Popul. Space Place 2010, doi: 10.1002/psp.634.

2. de Haas, H. The Myth of Invasion: The Inconvenient Realities of African Migration to Europe. Third World Q. 2008, 29, 1305-1322.

3. Castles, S.; Miller, M.J. The Age of Migration, 3rd ed.; The Guilford Press: London, UK, 2008.

4. King, R.; Black, R.; Collyer, M.; Fielding, A.; Skeldon, R. People On the Move. An Atlas of Migration; University of California Press: Berkeley, CA, USA, 2010.

5. Appadurai, A. Modernity at Large. Cultural Dimensions of Globalization; University of Minnesota Press: Minneapolis, MN, USA, 1996.

6. Vertovec, S. Migrant Transnationalism and Modes of Transformation. Int. Migrat. Rev. 2004, 38, 910-1001.

7. Fernández-Ardevol, M.; Ros Híjar, A. Communication Technologies in Latin America and Africa: A Multidisciplinary Perspective; IN3: Barcelona, Spain, 2009; pp. 23-35.

8. de Bruijn, M. 'The Telephone Has Grown Legs'. Mobile Communication and Social Change in the Margins of African Society; African Studies Centre: Leiden, The Netherlands, 2008.

9. Barten, J. Families in Movement. Transformation of the Family in Urban Mali, with a Focus on Intercontinental Mobility; African Studies Centre: Leiden, The Netherlands, 2009.

10. Jónsson, G. Migration Aspiration and Immobility in a Malian Village. IMI Working Papers No. 10. International Migration Institute: Oxford, UK, 2008.

11. Laitinen, I. Frontex and African Illegal Migration to Europe. In Africa and Fortress Europe. Threats and Opportunities; Gebrewold, B., Ed.; Ashgate: Aldershot, UK, 2007; pp. 127-138.

12. Broeders, D. The New Digital Borders of Europe. EU Databases and the Surveillance of Irregular Migrants. Int. Sociol. 2007, 22, 71-92.

13. Adepoju, A.; Van Noorloos, F.; Zoomers, A. Europe's Migration Agreements with MigrantSending Countries in the Global South: A Critical Review. Int. Migrat. 2010, 48, 42-75. 
14. Bensaad, A. The Mediterranean Divide and its Echo in the Sahara: New Migratory Routes and New Barriers on the Path to the Mediterranean. In Between Europe and the Mediterranean; Fabre, T., Sant-Cassia, P., Eds.; Palgrave: New York, NY, USA, 2007; pp. 51-70.

15. These deaths are counted by the No Border network since December 2002. Available online: http://www.noborder.org/dead.php (accessed on 11 August 2009).

16. Van Houtum, H.; Boedeltje, F. Europe's Shame. Death at the Borders of the EU. Antipode 2009, 41, 226-230.

17. Papastergiadis, N. The Turbulence of Migration. Globalization, Deterritorialization and Hybridity; Polity Press: Cambridge, UK, 2000.

18. Schapendonk, J. Turbulent Trajectories. Sub-Saharan African Migrants Heading North; Faculty of Management Sciences, Radboud University: Nijmegen, The Netherlands, 2011.

19. Schapendonk, J. Staying Put in Moving Sands. The Stepwise Migration Process of Sub-Saharan African migrants Heading North. In Respacing Africa; Engel, U.; Nugent, P., Eds.; Brill: Leiden, The Netherlands, 2010; pp. 113-139.

20. Collyer, M. In-Between Places: Trans-Saharan Transit Migrants in Morocco and the Fragmented Journey to Europe. Antipode 2007, 39, 668-690.

21. Hamood, S. African Transit Migration Through Libya to Europe: The Human Cost; The American University: Cairo, Egypt, 2006.

22. Daniş, D. Integration in Limbo: Iraqi, Afghan, Maghrebi and Iranian Migrants in Istanbul. MireKoc Research Projects. Koç University: Istanbul, Turkey, 2006.

23. Triandafyllidou, A.; Maroukis, T. The Case of the Greek Islands: The Challenge of Migration at the EU's Souteastern Sea Border. In Immigration Flows and the Management of the EU'S Southern Maritime Borders; Pinyol, G., Ed.; CIDOB: Barcelona, Spain, pp. 63-82.

24. Collyer, M. Euro-African Relations in the Field of Migration, 2008. In The Mediterranean Yearbook; IEM: Barcelona, Spain, 2009.

25. Schenkel, M. Outsourcing Asylum Seekers the Italian Way. Available online: http://vorige.nrc.nl/article2309813.ece (accessed on 8 December 2011).

26. González Enríquez, C. Spain. In European Immigration. A Sourcebook; Triandafyllidou, A., Gropas, R., Eds.; Ashgate: Hampshire, UK, 2007; pp. 321-333.

27. Collyer, M.; Düvell, F.; De Haas, H. Critical Approaches to Transit Migration. Popul. Space Place 2010, doi: 10.1002/psp.630.

28. Collyer, M. When Do Social Networks Fail to Explain Migration? Accounting for the Movements of Algerian Asylum-Seekers to the UK. J. Ethnic Migrat. Stud. 2005, 31, 699-718.

29. Singer, A.; Massey, D.S. The Social Process of Undocumented Border Crossing Among Mexican Migrants. Int. Migrat. Rev. 1998, 32, 561-592.

30. Van Liempt, I. Navigating Borders: Inside Perspectives on the Process of Human Smuggling; IMISCOE: Amsterdam, The Netherlands, 2007.

31. Schapendonk, J. The Dynamics of Transit Migration: Insights into the Migration Process of Sub-Saharan African Migrants Heading for Europe. JDAAS 2009, 28, 171-203.

32. Papadopoulou-Kourkoula, A. Transit Migration. The Missing Link Between Emigration and Settlement; Palgrave Macmillan: Hampshire, UK, 2008. 
33. Halfacree, K.H.; Boyle, P.J. The Challenge Facing Migration Research: The Case for a Biographical Approach. Progr. Hum. Geogr. 1993, 17, 333-348.

34. Massey, D. For Space; Sage: London, UK, 2005.

35. Bærenholdt, J.O.; Granas, B. Mobility and Place. Enacting Northern European Peripheries; Ashgate: Hampshire, UK, 2008.

36. Carling, J. Migration in the Age of Involuntary Immobility: Theoretical Reflections and Cape Verdean Experiences. J. Ethnic Migrat. Stud. 2002, 18, 5-42.

37. Cresswell, T. Towards a Politics of Mobility. Environ. Plan. Soc. Space 2010, 28, 17-31.

38. Pascual-de-Sans, A. Sense of Place and Migration Histories. Idiotopy and Idiotope. Area 2004, 36, 348-357.

39. Schapendonk, J.; Van Moppes, D. Migration and Information: Images of Europe, Migration Encouraging Factors and En Route Information Sharing. Working Paper Migration and Development Series No. 16. Radboud University: Nijmegen, The Netherlands, 2007.

40. Grillo, R. Betwixt and Between: Trajectories and Projects of Transmigration. J. Ethnic Migrat. Stud. 2007, 33, 199-217.

41. Peters, P.; Kloppenburg, S.; Wyatt, S. Co-ordinating Passages: Understanding the Resources Needed for Everyday Mobility. Mobilities 2010, 5, 349-368.

42. Granovetter, M.S. The Strength of Weak Ties. Am. J. Sociol. 1973, 78, 1360-1380.

43. Leed, E.J. The Mind of the Traveler. From Gilgamesh to Global Tourism; BasicBooks: New York, NY, USA, 1991; p. 234.

44. Schapendonk, J. Migrants' Im/Mobilities On Their Way to Europe: Lost in Transit? Tijdschrift voor Economische en Sociale Geografie 2012, forthcoming.

45. Schapendonk, J. Moving and Mediating: A Mobile View on Sub-Saharan African Migration Towards Europe. In Communication Technologies in Latin America and Africa: A Multidisciplinary Perspective; Fernandez-Ardevol, M., Ros Hijar, A., Eds.; IN3: Barcelona, Spain, 2009; pp. 293-318.

46. Brewer, K.T.; Yükseker, D. A Survey on African Migrants and Asylum Seeker in Istanbul. MiReKoC Research Projects. Koç University: Istanbul, Turkey, 2006.

47. Texeire, F. At the Gates of Europe: Irregular Immigration and Malta; Institute for Political Studies: Rennes, France, 2006.

48. Skeldon, R. Migration and Development: A Global Perspective; Longman: Harlow, UK, 1997.

49. Van Houtum, H. Mapping Transversal Borders: towards a Choreography of Space. In Transnational Migrations, Cosmopolitanism and Dis-located Borders; Brambilla, C., Riccio, B., Eds.; Guaraldi Publishers: Rimini, Italy, 2010.

50. Cwerner, S.B. The Times of Migration. J. Ethnic Migrat. Stud. 2001, 27, 7-36.

(C) 2012 by the author; licensee MDPI, Basel, Switzerland. This article is an open access article distributed under the terms and conditions of the Creative Commons Attribution license (http://creativecommons.org/licenses/by/3.0/). 